\title{
More Than Just "Blowing off Steam": The Roles of Anger and Advocacy in Promoting Positive Outcomes at Work
}

\author{
Lisa T. Stickney ${ }^{1}$ and Deanna Geddes ${ }^{2}$ \\ 1 Management \& International Business, University of Baltimore, Baltimore, MD, U.S.A. \\ 2 Department of Human Resource Management, Fox School of Business, Temple University, Philadelphia, PA, U.S.A.
}

\section{Keywords \\ anger, emotional expression, change agents, advocacy, social support, conflict resolution.}

\section{Correspondence}

Lisa T. Stickney, Management \& International Business,

University of Baltimore, $1420 \mathrm{~N}$. Charles St., 21201 Baltimore, MD, U.S.A.

e-mail: Lstickney@ubalt.edu

\begin{abstract}
Employee anger can be suppressed or quieted so that angry individuals only vent frustrations to supportive colleagues, rather than approach those responsible or in an organizational position to help remedy the problematic situation. The Dual Threshold Model (Geddes \& Callister, 2007) argues that although these "muted anger" venting episodes may increase unfavorable organizational outcomes, they also may prompt participants or observers of these displays to engage in advocacy or surrogacy on behalf of an angry colleague. The research reported here empirically tests this proposition and reports that advocating on behalf of one's angry colleague can enhance individual relationships at work as well as organizational functioning. Findings also show that observer felt anger intensity is a primary motivator for prompting anger advocacy and, surprisingly, advocacy is less likely on behalf of close colleagues.
\end{abstract}

Increased attention toward emotional aspects of employees indicates a growing realization that these are unique and prevalent phenomena impacting daily interactions and operations. Ongoing organizational and management scholarship offer evolving views of employee emotions. Theoretical frameworks of employee emotionality facilitate focused attention on emotional episodes and participants that generate and reflect intense feelings (Barsade, Brief, \& Spataro, 2003; Elfenbein, 2007; Geddes \& Callister, 2007; Van Kleef, Homan, \& Cheshin, 2012). Such models enhance our understanding of employee emotions and emotional responses within the social and conflict-ridden contexts in which they occur (Côté, 2005; Fineman, 1993, 2000; Gibson \& Callister, 2010; Skjørshammer, 2003; Van Kleef, Van Doorn, Heerdink, \& Koning, 2011).

Recent scholarship studying workplace anger helps highlight this emotion from multiple new perspectives. Anger increasingly is characterized as having prosocial, in addition to antisocial associations. Rather than being synonymous with workplace aggression, hostility, and/or deviance, workplace anger has potential for initiating useful change and addressing injustice (Geddes \& Stickney, 2011; Lindebaum \& Geddes, 2015; Stickney \& Geddes, 2014). Focus has shifted from the angry employee for determining organizational outcomes to observers who witness and react to these displays. One model in particular, the Dual Threshold Model (DTM) of workplace anger adopts a dynamic social constructivist framework for predicting when more positive and more negative outcomes will emerge from anger expression (Geddes \& Callister, 2007). Using this model, we explore the role of observers and, specifically, third-party advocacy in response to an anger-eliciting situation at work. 


\section{Theoretical Framework and Hypotheses}

Geddes and Callister's (2007) DTM differentiates three forms of workplace anger-suppressed, expressed, and deviant - based on symbolic placement of an expression and an impropriety threshold. Suppressed anger is felt anger either kept to oneself or hidden from those who could appropriately deal with the anger-provoking incident. In other words, it fails to cross the organizational "expression threshold." When anger is displayed at work in a manner deemed by others as inappropriate, it also crosses an "impropriety threshold" and is dubbed "deviant anger." The thresholds symbolically represent the organization's emotion display norms. They are dynamic (vs. fixed) and can be placed close together or farther apart, with the latter allowing for greater expression of employee anger without sanctioning. Expressed anger, which occurs in the space between the two thresholds, is vocalized to relevant parties in a manner seen as appropriate for that work environment. In particular, expressed anger is seen as an "emotion-based form of employee voice" (Geddes \& Callister, 2007, p. 729). Consistent with Hirschman's (1970) classic definition, voice is an often challenging but proactive expression of dissatisfaction in an "attempt to change rather than escape from, an objectionable state of affairs" (p. 30). The DTM proposes that expressed anger can increase the likelihood of more positive individual, relational, and organizational outcomes. In contrast, suppressed and deviant anger can increase the likelihood of more negative outcomes from anger at work.

Suppressed anger takes two forms: "silent anger" and "muted anger." In the Dual Threshold Model, muted anger is used metaphorically — such as a mute apparatus on a musical instrument that softens and modifies the sound. Thus, muted anger expression is quieted or "muffled" so that those most able to help do not hear it (Geddes \& Stickney, 2012). Unlike silent anger, where felt anger is intentionally hidden from others, muted anger is an organizationally silent phenomenon (Morrison \& Milliken, 2000; Pinder \& Harlos, 2001), meaning anger is deliberately kept from management and those responsible for the problematic situation. Instead, frustrated employees vent their anger to colleagues, family, and friends who were uninvolved with the initial anger-provoking incident, but perceived as sympathetic and trustworthy (Brown, Westbrook, \& Challagalla, 2005; Bushman, 2002). While the angry employee may experience valued emotional relief and social support with muted anger displays (Albrecht \& Adelman, 1987; Burleson, 2003; Zellars \& Perrewé, 2001), the upsetting situation at work often remains unchanged and unresolved because management and/or those responsible for triggering the employee's anger remain unaware of its existence or impact.

Muted anger is a fairly prevalent phenomenon in the workplace. Of all the ways people cope with anger at work, the most common appears to be venting to someone other than the person with whom they were angry (Simon \& Nath, 2004). Studies examining individual responses to an anger-eliciting event report that $83 \%$ of upset employees told others about it (Fitness, 2000). Muted anger displays can often evoke reciprocal emotion management and social sharing of emotions (Fineman, 1993; Lively, 2000). In other words, angry employees venting to supportive colleagues often transfer their anger to individuals originally uninvolved or unaware of problematic situations, facilitating negative emotional contagion (Barsade, 2002; Cacioppo, \& Rapson, 1994). Overall, muted anger episodes often make problematic organizational circumstances worse and, in some cases, can be more damaging than intense, public, and “inappropriate" anger displays, characterized as deviant anger ${ }^{1}$ (Geddes \& Stickney, 2011).

Although muted anger displays are potentially quite problematic for management, the DTM does offer a noteworthy and hopeful caveat regarding this particular phenomenon. Specifically, Geddes and Callister (2007) propose that if the persons to whom angry employees vent will act as surrogates and/or advocates for their frustrated colleague, the probability of positive outcomes increases. According to the

\footnotetext{
${ }^{1}$ Deviant anger often involves intense, visible employee anger displays that violate an organization's emotion display norms and is depicted in the DTM as anger expression that crosses an organization's “impropriety threshold” (Geddes \& Callister, 2007).
} 
DTM, third-party observers who advocate on behalf of an emotional colleague - by expressing their own outrage to those able to respond appropriately to the problematic situation-facilitate anger crossing the expression threshold so that it is no longer organizationally silent. This suppressed anger transformation to "expressed anger" consequently enhances the possibility of more positive outcomes.

In the study reported here, we pursue this DTM proposition by examining subsequent emotions and communication practices of organizational members who listen to angry colleagues vent their frustration. In particular, we identify several possible antecedents to what we call "anger advocacy" or anger-triggered interactions (with varying degrees of expressed anger) by the observer to appropriate parties, in contrast to observers remaining silent or engaging in muted anger displays themselves. These antecedents include the angry employee's (hereafter referred to as "the actor") expressed anger intensity, the colleague witnessing this display's (hereafter referred to as "the observer"), expressed subsequent felt anger intensity, the actor's anger typicality, and the relational closeness of actor and observer. Finally, we examine observer anger advocacy's potentially positive impact on valued interpersonal and organizational outcomes.

\section{Anger Intensity of Actor and Observer}

We anticipate the likelihood of anger advocacy, where observers speak up assertively on behalf of emotional colleagues, would be a function of both the actor and observer's anger intensity regarding the emotional episode. Emotion intensity is seen as a somewhat neglected area of study (Jones, 2001; Laukka, Juslin, \& Bresin, 2005); nevertheless, it is perhaps the most salient and regulated dimension associated with both felt and expressed anger (Geddes \& Callister, 2007).

There are numerous factors contributing to anger intensity at work (Basch \& Fisher, 2000; Harlos, 2004; Weiss \& Cropanzano, 1996). For instance, employees can feel intense anger as a result of mistreatment by management, another colleague or client, or from more broad-based, adverse conditions that negatively impact the organization as a whole (Gibson \& Callister, 2010; Klaas, Olson-Buchanan, \& Ward, 2012; Lindebaum \& Jordan, 2014). Anger results when one's goals are blocked by another, and/or when social norm violations or injustices are apparent (Frijda, 1987; Scherer, Wranik, Sangsue, Tran, \& Scherer, 2004). The more frustrated one's goals are, the angrier the person should become (Averill, 1982; Gelbrich, 2010). Research examining intolerable situations at work, sexual harassment, for example, shows that with more severe cases, there is an increase in complaint filing among employees (Fitzgerald, Swan, \& Fischer, 1995). Pinder and Harlos (2001) argue that enhanced significance of unjust events increases the tendency of both "quiescent" and "acquiescent" employees to break their typical silence and engage in "remedial voice" (Harlos, 2010).

Logically, with more severe mistreatment, perceived indiscretions, goal thwarting, or injustice, employees will feel greater anger. Although the relationship between felt and expressed anger is complex and understudied (Cowie \& Cornelius, 2003; Laukka et al., 2005), it is reasonable to assume more intense felt anger can motivate the release of strong inhibitions as well as strong emotional expression by employees. Thus, with intensely felt anger, employees may be more inclined to express this strong emotion to those they perceive as "safe" and unlikely to sanction (Geddes \& Stickney, 2011).

Hypothesis 1: Intense anger displays by the actor will increase the likelihood of anger advocacy, rather than a subsequent muted anger response or silence from the observer.

Using "reverse appraisals" (Hareli \& Hess, 2012), the observer who views a colleague express anger at high intensity might perceive the situation at work as particularly serious and severe. In turn, this may provoke significant anger among interested observers. Merely observing anger displays also makes individuals susceptible to emotional contagion (Hatfield et al., 1994). Susceptibility to emotional contagion can result from more than mimicry, including focused attention on others, the ability to view oneself as interrelated with the angry individual, and one's ability to interpret another's emotion through voice, posture, and perspective-taking (Hatfield et al., 1994; Hawk, Fischer, \& Van 
Kleef, 2011). We anticipate observers who feel intense anger as a result of hearing of their colleague's anger-provoking situation, will overcome inhibitions to expressing anger, especially to those able to redress the problematic situation (Sonnemans \& Frijda, 1995). Those observing their colleague express anger who are not subsequently angered are unlikely to approach management or involved parties in an advocate capacity.

Hypothesis 2: Intense observer felt anger increases the likelihood of anger advocacy, rather than a subsequent muted anger response or silence from the observer.

\section{Typicality of Actor Anger Response}

The typicality of employee anger displays may also influence observer advocacy on their behalf. To many, workplace anger expressions are an occasional experience (Averill, 1982); however, research and practice show that certain individuals may regularly express negative affect and anger even in situations that are not considered anger-provoking. For example, habitual anger responses often result from trait anger and are used to classify particular anger episodes to increase their predictability (Böddeker \& Stemmler, 2000). Consequently, there may be individuals at work with behavioral or personality attributes that increase their tendency to express anger. Frequent occurrences of employee anger expression may lead organizational observers to become desensitized to such displays so that they give them minimal attention (Geddes \& Callister, 2007). An angry employee who regularly vents to his or her friends may be taken less seriously, especially if this expression is seen as a result of "angry habits" (Tavris, 1984) or a personality trait (Bradfield \& Aquino, 1999; Forgays, Forgays, \& Spielberger, 1997). Consequently, this perception would likely reduce one's inclinations to act assertively and beneficially on a colleague's behalf. Conversely, if it is rare for an employee to display anger, then actor anger would be particularly salient to observers who might be shocked and/or concerned by their colleague's display, increasing their tendency to assert themselves and help change a problematic work situation.

Hypothesis 3: Atypical colleague (actor) anger increases the likelihood of anger advocacy, rather than a subsequent muted anger response or silence from the observer.

\section{Relational Closeness}

Finally, we anticipate that closeness of the relationship between the two parties will increase observer anger advocacy (Tajfel \& Turner, 1985). Individuals seen as important in-group friends or colleagues, versus more peripheral to one's social network, are likely to receive particular attention and assistance during challenging work situations. Employee voice (vs. exit or silence) resulting from "loyalty" is increasingly linked to one's close social relationships with other members of the organization (Pauksztat, van Duijn, \& Wittek, 2011). In contrast to traditional views of Hirschman's (1970) exit-voice-loyalty framework, that assert loyalty — operationalized as organizational commitment-moderates the decision to voice one's dissatisfaction (Dowding, John, Mergoupis, \& Van Vugt, 2000), closeness and loyalty to one's colleagues appears to be key in promoting prosocial actions at work (Pauksztat et al., 2011). Anger advocacy would be seen as an expression of loyalty — to the individual, organization, or both — in efforts to ensure immediate and necessary changes at work.

Hypothesis 4: Relationship closeness increases the likelihood of anger advocacy, rather than a subsequent muted anger response or silence from the observer.

\section{Advocacy Impact on Outcomes}

We anticipate that employees advocating on behalf of their frustrated colleagues' situation can become intentional "change agents" or "change advocates" (Sims, 2002). By identifying a problem, or detecting 
"error" (see Argyris, 2008), change advocates help facilitate new (or modify existing) organizational policies and practices (Quinn \& Sonenshein, 2008). Thus, third-party advocates who approach management or responsible parties on behalf of their angry colleague can counteract organizational silence and ultimately promote beneficial organizational learning and change.

Organizational observers who listen to employees vent their anger do have options, however. They may (a) express themselves to responsible organizational personnel (anger advocacy), (b) engage in muted anger themselves (organizational silence) as they express transferred angst to additional unrelated individuals, or (c) choose to remain silent. We assert that if observers of muted anger displays are sufficiently motivated to advocate for their angry coworker, the problematic situation is exposed and the employee is likely to feel gratitude for the instrumental support of this colleague (Geddes \& Callister, 2007). Positive change occurs as the troublesome condition at work improves, along with the parties' personal relationship.

Hypothesis 5: Anger advocacy on behalf of one's colleague, in contrast to a muted anger response or silence, enhances (a) the existing interpersonal relationship between actor and observer and (b) positive change in the organization.

\section{Method}

\section{Participants and Procedures}

We surveyed 210 working individuals regarding anger in the workplace. Of these respondents, 152 (72\%) acknowledged participation in a muted anger episode, which we defined as situations where a colleague expressed anger to them about some workplace situation in which the survey respondent (i.e., observer) was not previously involved. These survey participants were asked to provide additional information.

Data provided for analysis included their understanding of the anger-eliciting situation, their knowledge of and relationship to the angry organizational member, their emotional and communicative response to the situation, and what they believed to be the ultimate outcome of the underlying situation that evoked the actor's anger. The survey was completed by employed associates of students from a large urban university and a midsized urban university, both in the Mid-Atlantic region of the United States. The survey was administered online. Students were provided a link to a secure website containing the survey and instructed to forward the link to a full-time employee, asking that individual to complete the survey. Students received class participation credit for completed surveys.

All survey respondents were employed full-time. Fifty-one percent were female. Most (65\%) indicated their race as Caucasian, followed by African-American (20\%), Asian or Pacific Islander (9\%), Latino $(2 \%)$, and other $(4 \%)$. Fifty-four percent were under the age of 30, 21 percent reported being 31 to 40 years old, 15 percent were $41-50$ years old, and 10 percent listed their age as over 50 . Thirty percent indicated being employed at their current organization for more than one year but less than three years, 21 percent between three and five years, 20 percent between five and ten years, 15 percent for more than ten years, and 14 percent were employed less than one year.

\section{Measures}

\section{Independent Variables}

Actor anger intensity (expressed) was measured by combining scores for two items, 1) "how angry was your colleague" ( 1 = mildly angry, $10=$ extremely angry $)$, and "how visible was your colleague's anger" $(0=$ anger not visible, $10=$ anger extremely obvious $)$. Cronbach's alpha was .92 . Observer anger intensity (felt) was assessed with an 11-point scale adopted in previous research $(0=I$ felt no anger at all, $1=I$ felt 
mild anger, and $10=$ I felt extreme anger; Gibson, Schweitzer, Callister, \& Gray, 2009). Respondent (observer) perception of the actor's anger typicality was assessed with the question: "How characteristic or typical of this individual was the fact that she/he was angry?" This item was measured on a ten-point scale $(1=$ not very typical, $10=$ very typical $)$.

Relational closeness between the actor and observer was assessed using four sets of opposing adjectives anchored on a 7-point scale. The adjective sets were "not friendly-friendly," "casual acquaintanceclose friend," "rarely see person - constantly see person," and "rarely talk—constantly talk." Factor analysis of these items produced one factor explaining $42.7 \%$ of the variance in the items with a Cronbach's alpha of .72. The average of these four items produced our measure of relational closeness with higher scores indicating closer relationships.

\section{Outcome Variables}

We identified survey respondents' subsequent behavior following their interaction with the angry colleague using a check list of possible responses. Respondents indicated with whom they communicated following their interaction with the angry employee. Options included the following: "I communicated with..." (1) the person who triggered the employee's anger, (2) management, (3) coworkers unrelated to the situation, (4) someone outside of work, and (5) "I didn't communicate with anyone." Respondents were asked to check all that applied. These correspond to DTM conceptualizations (Geddes \& Callister, 2007) and possible responses by the observer, including the following: observer anger advocacy (items 1 and 2), observer muted response (items 3 and 4), and observer silence (item 5). Thus, anger advocacy identifies respondents (observers) who communicated with an individual in a position to affect change (i.e., the person who triggered the employee's anger or management). Respondents who communicated with unrelated coworkers or someone outside of work were classified as "muted," and respondents who did not communicate with anyone were classified as "silent." In the test of Hypotheses 1 through 4, observer anger response served as the dependent variable, and a single categorical variable was created to include the three observer communication options: anger advocacy (3), muted response (2), and silence (1). However, in the test of Hypothesis 5, observer response variables served as independent variables and were dummy-coded $(1=$ selected, $0=$ not selected $)$ individually.

Change as a result of the muted anger situation was measured both individually and organizationally. Using a five-point scale ( 1 = strongly disagree, 5 = strongly agree), personal outcome was the average of four items that asked respondents to reflect on the initial conversation with their angry colleague: "I'm glad the person came to me with his/her problem"; "I feel I helped the person with the situation"; "I would have preferred that the person had not come to me with the problem" (reverse-coded); and "I feel our relationship was strengthened as a result of this situation." A factor analysis of these items produced a one-factor solution that explained $46.7 \%$ of the variance in the items. The alpha reliability coefficient for personal outcome was .76.

Organizational outcome was measured by averaging four items from Stickney and Geddes' (2014) study of workplace anger. The items were measured on a five-point scale $(1=$ strongly disagree, 5 = strongly agree) and were adapted for this study of muted anger by asking about the situation that made the respondent's colleague angry instead of making the respondent angry (e.g., "The specific situation that made them angry got better" and "Their relationship with those involved improved"). The Cronbach's alpha for organizational outcome was .91. However, we recognize the possibility of a social desirability bias in this measure in that employees who advocated on behalf of a colleague would like to believe their actions were effective and would indicate the situation improved. Thus, we examined this organizational outcome measure further. Among respondents who were classified as anger advocates, the mean score for this dependent variable $(3.34 ; S D=.97)$ and median (3.5) were fairly low. Also, the distribution of responses for organizational outcome was fairly broad with only slightly more than one third $(34.3 \%)$ of the respondents indicating they believed the situation improved (a score of 4 or higher) after advocating. Given these results, we do not believe social desirability significantly biased this measure. 


\section{Control Variables}

Control variables were included because prior research shows them to be related to either anger expression or workplace outcomes following anger expression. Demographic control variables included advocate gender ( 1 = male, 0 = female; Domagalski \& Steelman, 2007), age $(1=$ age 30 and under, $2=$ age 31 to $40,3=$ age 41 to 50, $4=$ age 51 to 60 , and $5=$ over 60 years; O'Neill, Vandenberg, DeJoy, \& Wilson, 2009), and race $(1=\text { white, } 0=\text { nonwhite; Maier et al., 2009 })^{2}$ We also controlled for respondent perceptions of their work environment (Skjørshammer, 2003) and used Geddes and Stickney's (2011) measure. We averaged responses to five forced-choice adjective pair items using a 7-point scale. Sample items included "hostile-friendly" and "obstructive-supportive." Higher scores reflected perceptions of a more positive, supportive work environment. The alpha reliability coefficient for these items was .85 .

\section{Results}

Table 1 reports descriptive statistics and correlations for study variables relevant to the muted anger episode survey respondents observed. Overall, respondents felt the situation was moderately serious $(M=5.5, S D=2.5)$, and believed their level of anger $(M=4.1, S D=2.8)$ was lower than their colleague's $(M=6.6, S D=2.1)$. Respondents also felt that their colleague's (actor) anger was moderately typical $(M=5.5, S D=2.5)$, and generally characterized themselves as having a good relationship $(M=5.6, S D=.92)$. The majority $(53 \%)$ of survey respondents, following their involvement in the muted anger episode, indicated they remained silent, speaking with no one else, while $34 \%$ reported communicating to an unrelated individual (muted response), and $23 \%$ reported communicating with a manager or an individual involved in the anger-provoking situation (advocacy) ${ }^{3}$

Hypotheses 1 to 4 predicted conditions in which observers would engage in advocacy on behalf of their angry colleague, rather than a muted or silent response. Given the categorical nature of the dependent variable (expressed, muted, silent), we tested these hypotheses using a generalized linear model (GZLM) with maximum-likelihood estimates. GZLM is an extension of the general linear model but is a separate analysis with different assumptions. GZLM is appropriate when dependent variables are nonparametric such as binary and categorical data (Garson, 2010), and the use of maximum-likelihood estimates is recommended because they do not require an assumption of normal distributions (Agresti, 2007).

Table 2 contains results from the generalized linear models testing Hypotheses 1 to 4 . In a GZLM, the likelihood ratio chi-square is the overall test of model significance, and the Wald chi-square statistic indicates the significance of individual predictor variables. In our model, the likelihood ratio chi-square test was significant for the overall model $\left(X^{2}=20.17_{(11)}, p<.05\right)$. However, since GZLM calculates a parameter estimate for every possible value of categorical control and predictor variables, we list the Wald chisquare statistic and only report betas for significant parameters.

Hypothesis 1 predicted that the likelihood of observer anger advocacy would be greater with higher intensity actor anger displays. This hypothesis was not supported as indicated by the nonsignificant Wald chi-square for actor anger intensity. However, there was support for Hypothesis 2. The significant coefficient for observer anger intensity $(b=.06, S E=.03, p<.05)$ indicated observers were more likely to engage in advocacy for their angry colleague under conditions of more intensely felt personal anger.

Hypothesis 3 expected observer anger advocacy when actor anger was atypical. However, the nonsignificant Wald chi-square for typicality of actor anger indicates no support for this hypothesis.

\footnotetext{
${ }^{2}$ Observer status in relation to actor was originally included in the analysis, but was nonsignificant. Further, the vast majority (79.6\%) of the respondents indicated a peer relationship (vs. superior or subordinate) with the angry colleague. Given the lack of variance and significance, we did not retain it as a control.

${ }^{3}$ Among those who reported speaking to others about the anger-eliciting situation, only $8.6 \%$ reported speaking to both someone in a position to affect change and an unrelated individual. We counted this as anger advocacy given they did communicate to a situation-relevant other.
} 


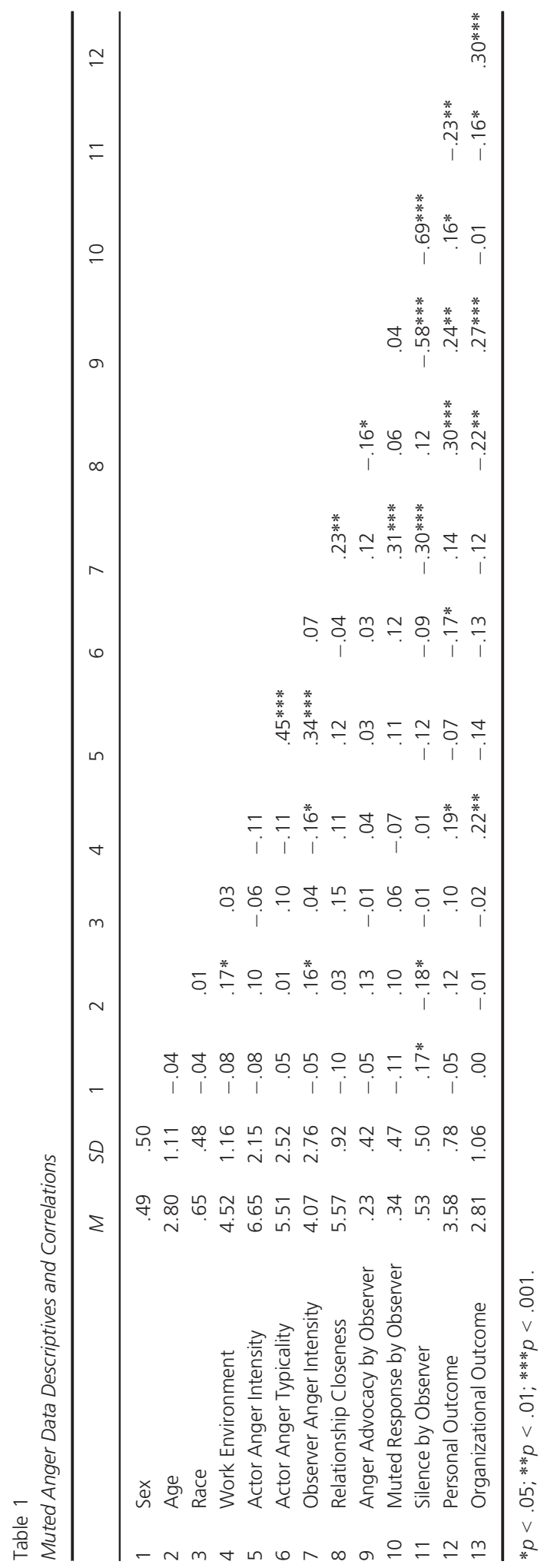


Table 2

Wald Chi-square Statistics for Predictors of Anger Advocacy

\begin{tabular}{lcc}
\hline & Anger Advocacy & $d f$ \\
\cline { 2 - 3 } & Wald $\chi^{2}$ & 1 \\
\hline Intercept & $12.79 * * *$ & 1 \\
Sex & 3.05 & 4 \\
Age & 3.49 & 1 \\
Race & .23 & 1 \\
Work Environment & 1.23 & 1 \\
Actor Anger Intensity & .05 & 1 \\
Actor Anger Typicality & .57 & 1 \\
Observer Anger Intensity & $4.68 *$ & 1 \\
Relationship Closeness & $4.59 *$ & 11 \\
Likelihood Ratio Chi-square & $20.17 *$ & \\
\hline
\end{tabular}

Note. Chi-squares do not reflect the sign of the parameter estimates for predictor variables. However, Relationship between Actor and Advocate was negatively associated with Anger Advocacy. All other significant predictors were positively related to Anger Advocacy.

$* p<.05 ; * * p<.01 ; * * * p<.001$.

Hypothesis 4 predicted that the likelihood of advocate anger expression would increase with a close relationship between observer and actor. The coefficient for relationship between actor and observer was significant $(b=-.17, S E=.08, p<.05)$. However, contrary to our hypothesis, the coefficient was negative-indicating observer anger advocacy was more likely when the relationship between observer and actor was more distant. Thus, Hypothesis 4 was not supported.

Hypotheses $5 \mathrm{a}$ and $5 \mathrm{~b}$ predicted that observer anger advocacy would improve the actor-observer interpersonal relationship and the problematic situation at work, respectively. We tested these hypotheses with hierarchical regressions. Sex, age, race, and work environment control variables were entered in the first step with observer anger advocacy and observer muted response in the second step. Observer silence was the omitted category. The results can be found in Table 3. The overall regression model for personal outcome was significant $\left(F_{(6,113)}=3.11, p<.01\right)$ as was the change in $R^{2}$ in step $2\left(\Delta R^{2}=.06\right.$,

Table 3

Standardized Regression Coefficients Predicting Outcomes after Observer Anger Advocacy

\begin{tabular}{|c|c|c|c|}
\hline \multirow[b]{2}{*}{ Step } & & \multicolumn{2}{|c|}{ Situational Change } \\
\hline & & $\begin{array}{l}\text { Personal } \\
\text { Final } \beta\end{array}$ & $\begin{array}{l}\text { Organizationa } \\
\text { Final } \beta\end{array}$ \\
\hline \multirow[t]{4}{*}{1} & Sex & .02 & -.05 \\
\hline & Age & .09 & -.12 \\
\hline & Race & .06 & -.04 \\
\hline & Work Environment & $.21 *$ & $.29 * *$ \\
\hline \multirow[t]{5}{*}{2} & Observer Anger Advocacy & $.19 *$ & $.29 * *$ \\
\hline & Observer Muted Response & .15 & -.06 \\
\hline & Overall Model F & $3.11 * *$ & $3.82 * *$ \\
\hline & Change in $R^{2}$ at Step 2 & $.06 *$ & $.08 * *$ \\
\hline & Adjusted $R^{2}$ & .10 & .12 \\
\hline
\end{tabular}

Note. A positive $\beta$ indicates a positive change in the situation.

$* p<.05 ; * * p<.01 ; * * * p<.001$. 
$p<.05)$. The significant, positive coefficient $(\beta=.19, p<.05)$ on observer anger advocacy supports Hypothesis $5 \mathrm{a}$. Compared to silent observers who talked to no one after witnessing the muted anger display, observers who advocated on behalf of their angry colleagues perceived that their interpersonal relationship improved. Also supported was Hypothesis $5 \mathrm{~b}$. The overall model $\left(F_{(6,113)}=3.82, p<.01\right)$ and change in $R^{2}$ in step $2\left(\Delta R^{2}=.08, p<.01\right)$ were significant, as was the positive coefficient on observer anger advocacy $(\beta=.29, p<.01)$. These findings indicate that employee advocates who expressed their frustrations to a manager or the individual involved perceived felt that the anger-eliciting situation improved.

\section{Discussion}

This study explored the role of anger-prompted, third-party advocacy by empirically testing relevant propositions from the Dual Threshold Model of workplace anger (Geddes \& Callister, 2007). The DTM proposes that when a surrogate speaks up on behalf of an angered individual, the actor's anger is no longer organizationally silent, but crosses the expression threshold and, thus, increases the probability of positive consequences. Our findings indicate that observer anger advocacy is related to perceptions of positive change at both interpersonal and organizational levels. Interpersonally, advocates report an improved relationship with their angry colleague, and organizationally, they report positive changes regarding the situation that triggered the anger episode. These results support DTM propositions regarding the benefits of observer advocacy in muted anger episodes.

Respected colleagues and workplace friends are often approached when employees display muted anger. The DTM would argue these individuals may become angry in a sympathetic and/or justiceoriented response to their colleague's difficult situation. Other models offer additional perspective in support of these findings. In the Emotions as Social Influence (EASI) model, van Kleef (2009) posits that emotional expression provides information about the situation, affects the observer's emotions, and elicits affective reactions by the observer. Further, in the case of anger displays, the EASI model argues observers experience reactive emotions; that is, the observer becomes angry and/or engaged in more deliberate information processing (Van Kleef et al., 2012). This "epistemic motivation" (Kruglanski \& Webster, 1996) is seen to vary with situation, increasing when individuals feel more personally impacted or involved. Although our findings indicated observers were less relationally close to the actors for whom they advocated, the fact that their felt anger intensity was a significant predictor suggests that they (perhaps as a fellow organizational member) felt significantly impacted and motivated to engage in deliberate, change-oriented interactions with relevant others.

Interestingly, less than one quarter of our survey participants chose to advocate on behalf of their angry colleagues. Although this was surprising, we can explain this somewhat by findings of a metaanalysis on social support and stress reduction at work (Viswesvaran, Sanchez, \& Fisher, 1999). The scholars found that social support, which we see as a general category including anger advocacy, is rare when support is mobilized primarily in the presence of stressors. Instead, social support and supportive environments appear primarily to reduce stress in the first place, rather than emerging as a response to stressful situations. Another possible explanation is linked to status and power. Kuppens, Van Mechelen, and Meulders (2004) report that approach behaviors (anger-out, assertion, reconciliation) are more likely to occur toward lower status individuals, while avoidance behaviors (anger-in or social sharing) are more likely to occur when the target is of higher status (Kuppens et al., 2004). Anger advocacy involved expressing concerns (and even anger) to either management or individuals responsible for another's angst. Unless both groups were peers of the advocate, or with lower status, the most typical response would be avoidance, or in the DTM vernacular, muted expression or silence. Overall, the notions of employee silence or voice are complicated, multidimensional phenomena and require ongoing research (Van Dyne, Ang, \& Botero, 2003). 
Ultimately, our greatest interest was what prompted observers of muted anger displays to advocate, as it appears to be a relatively uncommon phenomenon. The actor's anger display intensity did not appear to prompt this prosocial act of speaking up and addressing the problem, neither did the atypicality of their anger. Only if observers' felt anger was sufficiently intense after listening to their angry colleague did they approach and advocate to responsible parties. These findings suggest observer anger advocacy motivation is less instrumental and more emotion-driven, supporting Frijda's $(1987,2004)$ work showing emotion's link to action tendencies. We suggest that intensity of this feeling appears related to the extent to which an observer is willing to advocate on behalf of another. Further, this result is consistent with research identifying the benefits of supportive responses to intense/deviant anger displays at work (Geddes \& Stickney, 2011). Specifically, when employee anger displays violate organizational emotion display norms, that is, "deviant workplace anger," study findings showed that more supportive responses-versus sanctioning or doing nothing-lead to favorable organizational change. In the study reported here, we found a high correlation between employee (actor) expressed anger intensity and observer felt anger intensity $(r=.34$, $p<.001)$. This suggests that more intense anger displays by colleagues may trigger more anger by organizational observers.

Particularly surprising was our finding that a lack of relational closeness between observer and actor predicted expressed anger advocacy. However, extant theory and research offer possible explanations. The concept of "the strength of weak ties" suggests that casual acquaintances often provide better access to information and resources than close friends within a social circle (Granovetter, 1973, 1983). In addition, psychologically close employees may view their primary role with muted anger episodes as providing emotional support (Burleson, 2003). Alternatively, they may feel that assertive advocacy on their friend's behalf will be judged as less objective, more biased, and/or personally motivated. Recent studies also offer insight on limitations of emotionally supportive responses to those who vent anger. Behfar and Cronin (2010) report listener responses to venting that focused only on emotion support (unburdening) did not enhance postventing problem-solving, while listeners offering a more instrumental response (present-focused understanding) did. Recent scholarship examining "moral anger" would recognize anger advocacy as an example of such instances, where individuals experience and express significant anger when injustices or moral code violations hurt others (including complete strangers) - even at potential risk to themselves (Lindebaum \& Geddes, 2015). Observer anger advocacy expressions are highly instrumental in their outcome, while relatively emotional in their emergence. Overall, anger advocacy, while somewhat rare in organizational settings, nevertheless appears to be a beneficial practice that enhances workplace relationships and functioning.

\section{Limitations}

There are limitations to this study. We acknowledge that the use of a nonrandom, U.S. and socialnetwork sample limits the generalizability of our findings. Also acknowledged are established concerns regarding the use of self-report, cross-sectional data. Given the sensitive nature of asking about anger in the workplace, we chose to utilize an anonymous survey for data collection. Another concern about self-report data is common method variance (CMV) being introduced as an artifact of the data collection technique (Crampton \& Wagner, 1994; Doty \& Glick, 1998). Harman's one-factor test is a diagnostic tool designed to assess the extent CMV is present (Podsakoff \& Organ, 1986). If CMV is present, a one-factor solution is expected. We tested our data using this technique, which produced a five-factor solution explaining $44 \%$ of the variance in the underlying items. This indicates that $\mathrm{CMV}$ is not a serious threat in our analyses.

Potentially more problematic is the use of retrospective measures in our study. A great deal of research indicates that recollections are subject to cognitive bias (Dickson, Rainey, \& Hargie, 2003; Fisher, 2002; O’Neill et al., 2009; Schwarz, 2000; Weiss \& Cropanzano, 1996). However, there are conditions under 
which recollections can be more accurate and episodic memory available through reconstructed recall (Kain, 2004; Robinson \& Clore, 2002). Studies show accuracy in recall increases when the event occurs recently (Robinson \& Clore, 2002) and when stimuli are salient (Harlos \& Pinder, 2000). Respondents in our study described a recent muted anger incident. Over half (51\%) report an event that occurred the week prior to data collection, $25 \%$ within the prior month. Only $24 \%$ reported an anger event occurring later than a month prior to data collection. Also, given the prevalence of organizational norms for controlling anger expression (Gibson \& Callister, 2010) combined with the taboo of anger expression for many in organizations (Domagalski \& Steelman, 2007), anger episodes are likely to be particularly salient and more easily recalled.

\section{Future Research}

Taken together, our results provide additional support for the Dual Threshold Model of workplace anger, although more empirical research testing its propositions is necessary. Our research provides support for the benefits of observer anger advocacy in muted anger situations; nevertheless, many questions remain and more research is required to fully understand this phenomenon. While our study shows approximately one quarter of respondents report engaging in advocacy, future research needs to determine if this percentage is truly representative. Over half (53\%) of our respondents report they chose not to speak to anyone after hearing their colleague's anger about the problematic situation. This suggests they viewed their role as purely supportive, especially since actor anger display intensity did not predict advocacy. Future research should examine the extent of and contributing factors for observers witnessing workplace anger displays to engage in communication behaviors that initiate beneficial organizational change.

Given the relatively small number of colleagues willing to speak up on behalf of angry coworkers, future research should consider potential moderators of advocacy. Power at work is identified as an important moderator for third parties to act in the event of a perceived organizational injustice (O’Reilly \& Aquino, 2011). Observers with higher levels of power are more likely to engage in approach behaviors while those with low power are more likely to engage in avoidance behaviors. In our study, those willing to advocate on behalf of their colleagues were primarily peers or subordinates (79.4\%). Thus, while position power (hierarchical status) undoubtedly helps facilitate advocacy tendencies, other sources of power such as resource power may also be a significant moderator for predicting advocacy (O’Reilly \& Aquino, 2011).

Individual differences are also likely moderators of propensity toward anger advocacy. What personality traits impact one's tendency to express anger (however intense or mild) on behalf of another's emotional suffering? Those with strong proactive personality traits may be more likely to feel moved to act in an advocacy position when a perceived injustice is exposed. Extroverts and those with positive affectivity traits may be more likely to advocate on behalf of an angered coworker. In contrast, employees who are emotionally exhausted or with negative trait affectivity may be more likely to engage in a muted anger response (gossiping or further venting) or remain silent, rather than to seek out and voice concerns to those able to respond appropriately to their colleague's problematic situation. Folger's (2001) notion of deontic justice, "a psychological state yielding emotionally charged reactions to events seen as violating moral norms about social conduct," also is highly relevant to this line of research (O'Reilly \& Aquino, 2011, p. 527-529). Those who feel their colleagues are victims of unfair or inappropriate treatment at work are more likely to experience intense emotions (Spencer \& Rupp, 2009), including moral anger (Lindebaum \& Geddes, 2015). Consequently, they may be motived to engage in anger advocacy on behalf of coworkers (see De Cremer \& Van Hiel, 2006; Skarlicki \& Rupp, 2010).

Employee attitudes toward their organization may also be fertile ground for future research examining the willingness to advocate on behalf of angry and upset coworkers. Recent studies indicate that 
organizational commitment may affect an advocate's propensity to communicate with others (Geddes \& Stickney, 2012). Other attitudes that may affect an individual's decision to act as an advocate include job satisfaction and the tendency to engage in organizational citizenship behaviors (OCBs). Geddes and Callister (2007) argue that expressed anger is a form of employee voice. Relatedly, Farrell and Rusbult's (1992) meta-analysis shows job satisfaction associated with greater tendencies toward voice and loyalty. As for OCB propensity, an individual inclined to engage in OCBs might be more likely to advocate on behalf of another - especially if that individual perceives advocacy as helping behavior, one dimension of OCB (Podsakoff, MacKenzie, Paine, \& Bachrach, 2000). Increasing attention is being given to advocacy as a helping behavior, as recent research has shown it to have performance benefits to the advocate (Shah, Cross \& Levin, 2015).

In conclusion, although muted anger/venting episodes often promote problematic outcomes such as negative emotional contagion, we find that advocates can emerge from these emotional episodes. Observer anger advocacy allows suppressed, muted employee anger to cross an organizational expression threshold and thus increase the likelihood of positive workplace consequences. Our results indicate a third-party advocating to an individual in a position to affect change enhances individual relationships and organizational functioning. Findings also show that observer felt anger intensity is a primary motivator for prompting anger advocacy - initiating necessary, even heated conversations to address a problematic situation for their associate, and perhaps the organization as a whole.

\section{References}

Agresti, A. (2007). An introduction to categorical data analysis (2nd ed.). Hoboken, NJ: Wiley-Interscience.

Albrecht, T. L., \& Adelman, M. B. (1987). Communicating social support. Newbury Park, CA: Sage.

Argyris, C. (2008). Teaching smart people how to learn. Boston: Harvard Business Press.

Averill, J. R. (1982). Anger and aggression: An essay on emotion. New York: Springer-Verlag.

Barsade, S. G. (2002). The ripple effect: Emotional contagion and its influence on group behavior. Administrative Science Quarterly, 47, 644-675. doi:10.2307/3094912

Barsade, S. G., Brief, A. P., \& Spataro, S. E. (2003). The affective revolution in organizational behavior: The emergence of a paradigm. In J. Greenberg (Ed.), OB: The state of the science (2nd ed., pp. 3-52). Hillsdale, N.J.: L. Erlbaum Associates.

Basch, J., \& Fisher, C. (2000). Affective events-emotion matrix: a classification of work events and associated emotions. In N. M. Ashkanasy, C. E. J. Hartel \& W. J. Zerbe (Eds.), Emotions in the Workplace: Theory research and practice (pp. 36-48). Westport, CT: Quorum Pub.

Behfar, K., \& Cronin, M. (2010). Venting about work related annoyances: How the responses of third-party listeners impact the venter's ability to problem solve. Paper presented at the annual meeting of the Academy of Management, Montréal, Canada.

Böddeker, I., \& Stemmler, G. (2000). Who responds how and when to anger? The assessment of actual anger response styles and their relation to personality. Cognition and Emotion, 14, 737-762. doi:10.1080/ 02699930050156618

Bradfield, M., \& Aquino, K. (1999). The effects of blame attributions and offender likeableness on forgiveness and revenge in the workplace. Journal of Management, 25, 607-631. doi:10.1177/014920639902500501

Brown, S. P., Westbrook, R. A., \& Challagalla, G. (2005). Good cope, bad cope: Adaptive and maladaptive coping strategies following a critical negative work event. Journal of Applied Psychology, 90, 792-798. doi:10.1037/00219010.90.4.792

Burleson, B. R. (2003). The experience and effects of emotional support: What the study of cultural and gender differences can tell us about close relationships, emotion and interpersonal communication. Personal Relationships, 10, 1-23. doi:10.1111/1475-6811.00033

Bushman, B. J. (2002). Does venting anger feed or extinguish the flame? Catharsis, rumination, distraction, anger and aggressive responding. Personality and Social Psychology Bulletin, 28, 724-731. doi:10.1177/ 0146167202289002 
Côté, S. (2005). A social interaction model of the effects of emotion regulation on work strain. Academy of Management Review, 30, 509-530. doi:10.5465/AMR.2005.17293692

Cowie, R., \& Cornelius, R. R. (2003). Describing the emotional states that are expressed in speech. Speech Communication, 40, 5-32. doi:10.1016/S0167-6393(02)00071-7

Crampton, S. M., \& Wagner, J. A. (1994). Percept-percept inflation in microorganizational research: An investigation of prevalence and effect. Journal of Applied Psychology, 79, 67-76. doi:10.1037/0021-9010.79.1.67

De Cremer, D., \& van Heil, A. (2006). Effects of another person's fair treatment on one's own emotions and behaviors: The moderating role of how much the other cares for you. Organizational Behavior and Human Decision Processes, 100, 231-249. doi:10.1016/j.obhdp.2005.10.002

Dickson, D. A., Rainey, S., \& Hargie, O. D. W. (2003). Communicating sensitive business issues: Part 2. Corporate Communications: An International Journal, 8, 121-127. doi:10.1108/1356328031047562

Domagalski, T. A., \& Steelman, L. A. (2007). The impact of gender and organization status on workplace anger expression. Management Communication Quarterly, 20, 297-315. doi:10.1177/0893318906295681

Doty, D. H., \& Glick, W. H. (1998). Common methods bias: Does common methods variance really bias results? Organizational Research Methods, 1, 374-406. doi:10.1177/109442819814002

Dowding, K., John, P., Mergoupis, T., \& Van Vugt, M. (2000). Exit, voice and loyalty: Analytic and empirical developments. European Journal of Political Research, 37, 469-495. doi:10.1111/1475-6765.00522

Elfenbein, H. A. (2007). Emotion in organizations: A review and theoretical integration. Academy of Management Annals, 1, 371-457. doi:10.1080/078559812

Farrell, D., \& Rusbult, C. E. (1992). Exploring the exit, voice, loyalty, and neglect typology: The influence of job satisfaction, quality of alternatives, and investment size. Employee Responsibilities and Rights Journal, 5, 201-218. doi:10.1007/BF01385048

Fineman, S. (1993). Emotion in organizations. Newbury Park, CA: Sage.

Fineman, S. (2000). Emotion in organizations (2nd ed.). Thousand Oaks, CA: Sage.

Fisher, C. D. (2002). Antecedents and consequences of real-time affective reactions at work. Motivation and Emotion, 26, 3-30. doi:10.1023/A:1015190007468

Fitness, J. (2000). Anger in the workplace: An emotion script approach to anger episodes between workers and their superiors, co-workers, and subordinates. Journal of Organizational Behavior, 21, 147-162.

Fitzgerald, L., Swan, S., \& Fischer, K. (1995). Why didn't she just report him? The psychological and legal implications of women's responses to sexual harassment. Journal of Social Issues, 51, 117-138. doi:10.1111/j.15404560.1995.tb01312.x

Folger, R. (2001). Fairness as deonance. In S. W. Gilliland, D. D. Steiner \& D. P. Skarlicki (Eds.), Research in social issues in management (pp. 3-31). Greenwich, CT: Information Age Publishers.

Forgays, D. G., Forgays, D. K., \& Spielberger, C. D. (1997). Factor structure of the state-trait anger expression inventory. Journal of Personality Assessment, 69, 497-507. doi:10.1207/s15327752jpa6903_5

Frijda, N. H. (1987). Emotion, cognitive structure, and action tendency. Cognition and Emotion, 1, $115-143$. doi:10.1080/02699938708408043

Frijda, N. H. (2004). Emotions and action. In A. S. R. Manstead, N. Frijda \& A. Fischer (Eds.), Feelings and emotions: The Amsterdam symposium (pp. 158-173). New York, NY: Cambridge University Press.

Garson, G. D. (2010). Generalized linear models and generalized estimating equations. http://faculty.chass.ncsu.edu/garson/pa765/statnote.htm. Accessed January, 10, 2011.

Geddes, D., \& Callister, R. R. (2007). Crossing the line(s): A dual threshold model of anger in organizations. Academy of Management Review, 32, 721-746. doi:10.5465/AMR.2007.25275495

Geddes, D., \& Stickney, L. T. (2011). The trouble with sanctions: Organizational responses to deviant anger displays at work. Human Relations, 64, 201-230. doi:10.1177/0018726710375482

Geddes, D., \& Stickney, L. T. (2012). Muted anger in the workplace: Changing the "sound" of employee emotion through social sharing. In N. M. Ashkanasy, C. Härtel \& W. J. Zerbe (Eds.), Research on emotion in organizations (Vol. 8, pp. 85-103). Bingley, UK: Emerald Group Pub.

Gelbrich, K. (2010). Anger, frustration, and helplessness after service failure: Coping strategies and effective informational support. Journal of the Academy of Marketing Science, 38, 567-585. doi:10.1007/s11747-009-0169-6 
Gibson, D. E., \& Callister, R. R. (2010). Anger in organizations: Review and integration. Journal of Management, 36, 66-93. doi:10.1177/0149206309348060

Gibson, D. E., Schweitzer, M. E., Callister, R. R., \& Gray, B. (2009). The influence of anger expressions on outcomes in organizations. Negotiation and Conflict Management Research, 2, 236-262. doi:10.1111/j.17504716.2009.00039.x

Granovetter, M. S. (1973). The strength of weak ties. American Journal of Sociology, 78, 1360-1380.

Granovetter, M. S. (1983). The strength of weak ties: A network theory revisited. Sociological Theory, 1, 201-233. doi:10.2307/202051

Hareli, S., \& Hess, U. (2012). The social signal value of emotion. Cognition and Emotion, 26, 385-389. doi: 10.1080/02699931.2012.665029

Harlos, K. P. (2004). When bad things happen at work: A partial field test of affective events theory. Paper presented at the annual meeting of the Academy of Management, New Orleans.

Harlos, K. P. (2010). If you build a remedial voice mechanism, will they come? Determinants of voicing interpersonal mistreatment at work. Human Relations, 63, 311-329. doi:10.1177/0018726709348937

Harlos, K. P., \& Pinder, C. C. (2000). Emotion and injustice in the workplace. In S. Fineman (Ed.), Emotion in organizations (2nd ed., pp. 36-57). Thousand Oaks, CA: Sage.

Hatfield, E., Cacioppo, J. T., \& Rapson, R. L. (1994). Emotional contagion. Paris: Cambridge University Press.

Hawk, S. T., Fischer, A. H., \& Van Kleef, G. A. (2011). Taking your place or matching your face: Two paths to empathic embarrassment. Emotion, 11, 502-513. doi:10.1037/a0022762

Hirschman, A. O. (1970). Exit, voice, and loyalty: Responses to decline in firms, organizations, and states. Cambridge, MA: Harvard University Press.

Jones, T.S. (2001). Emotional communication in conflict: Essence and impact. In W.F. Eadie \& P.E. Nelson (Eds.), The language of conflict and resolution (pp. 81-104). CA, Sage: Thousand Oaks.

Kain, D. L. (2004). Owning significance: The critical incident technique in research. In K. B. DeMarrais \& S. D. Lapan (Eds.), Foundations for research: Methods of inquiry in education and the social sciences (pp. 69-85). Mahawah, NJ: L. Erlbaum Associates.

Klaas, B. S., Olson-Buchanan, J. B., \& Ward, A. (2012). The determinants of alternative forms of workplace voice: An integrative perspective. Journal of Management, 38, 314-345. doi:10.1177/0149206311423823

Kruglanski, A.W., \& Webster, D.M. (1996). Motivated closing of the mind: "Seizing" and "freezing”. Psychological Review, 103, 263-283. doi:doi.org/10.1037/0033-295X.103.2.263

Kuppens, P., Van Mechelen, I., \& Meulders, M. (2004). Every cloud has a silver lining: Interpersonal and individual differences determinants of anger-related behaviors. Personality and Social Psychology Bulletin, 30, 1550-1564. doi: $10.1177 / 0146167204271176$

Laukka, P., Juslin, P. N., \& Bresin, R. (2005). A dimensional approach to vocal expression of emotion. Cognition and Emotion, 19, 633-653. doi:10.1080/02699930441000445

Lindebaum, D., \& Geddes, D. (2015). The place and role of (moral) anger in organizational behavior studies. Journal of Organizational Behavior. doi:10.1002/job.2065

Lindebaum, D., \& Jordan, P. J. (2014). When it can be good to feel bad and bad to feel good: Exploring asymmetries in workplace emotional outcomes. Human Relations, 67, 1037-1050. doi:10.1177/0018726714535824

Lively, K. J. (2000). Reciprocal emotion management. Work and Occupations, 27, 32-63. doi:10.1177/ 0730888400027001003

Maier, K. J., Goble, L. A., Neumann, S. A., Giggey, P. P., Suarez, E. C., \& Waldstein, S. R. (2009). Dimensions across measures of dispositional hostility, expressive style, and depression show some variation by race/ethnicity and gender in young adults. Journal of Social and Clinical Psychology, 28, 1199-1225. doi:10.1521/ jscp.2009.28.10.1199

Morrison, E. W., \& Milliken, F. J. (2000). Organizational silence: A barrier to change and development in a pluralistic world. Academy of Management Review, 25, 706-725. doi:10.5465/AMR.2000.3707697

O’Neill, O. A., Vandenberg, R. J., DeJoy, D. M., \& Wilson, M. G. (2009). Exploring relationships among anger, perceived organizational support, and workplace outcomes. Journal of Occupational Health Psychology, 14, 318333. doi:10.1037/a0015852 
O’Reilly, J., \& Aquino, K. (2011). A model of third parties' morally-motivated responses to injustice. Academy of Management Review, 36, 526-543. doi:10.5465/AMR.2011.61031810

Pauksztat, B., van Duijn, M. A. J., \& Wittek, R. (2011). A 'special attachment': Voice and the relational aspect of loyalty. International Sociology, 26, 524-546. doi:10.1177/0268580910393374

Pinder, C. C., \& Harlos, K. P. (2001). Employee silence: Quiescence and acquiescence as responses to perceived injustice. Research in Personnel and Human Resources Management, 20, 331-369.

Podsakoff, P. M., MacKenzie, S. B., Paine, J. B., \& Bachrach, D. G. (2000). Organizational citizenship behaviors: A critical review of the theoretical and empirical literature and suggestions for future research. Journal of Management, 26, 513-563. doi:10.1177/014920630002600307

Podsakoff, P. M., \& Organ, D. W. (1986). Self-reports in organizational research: Problems and prospects. Journal of Management, 12, 531-544. doi:10.1177/014920638601200408

Quinn, R., \& Sonenshein, S. (2008). Four strategies of change. In T. Cummings (Ed.), Handbook of organization development (pp. 69-78). Newbury Park, CA: Sage.

Robinson, M. D., \& Clore, G. L. (2002). Belief and feeling: Evidence for an accessibility model of emotional selfreport. Psychological Bulletin, 128, 934-960. doi:10.1037/0033-2909.128.6.934

Scherer, K. R., Wranik, T., Sangsue, J., Tran, V., \& Scherer, U. (2004). Emotions in everyday life: Probability of occurrence, risk factors, appraisal and reaction pattern. Social Science Information, 43, 499-570. doi:10.1177/ 0539018404047701

Schwarz, N. (2000). Emotion, cognition, and decision making. Cognition and Emotion, 14, 433-440. doi:10.1080/ 026999300402745

Shah, N.P., Cross, R., \& Levin, D.Z. (2015). Performance benefits from providing assistance in networks: Relationships that generate learning. Journal of Management, doi:10.1177/0149206315584822

Simon, R. W., \& Nath, L. E. (2004). Gender and emotion in the United States: Do men and women differ in selfreports of feelings and expressive behavior? American Journal of Sociology, 109, 1137-1176. doi:10.1086/382111

Sims, R. R. (Ed.) (2002). Changing the way we manage change. Westport, CT: Greenwood Publishing Group.

Skarlicki, D. P., \& Rupp, D. E. (2010). Dual processing and organizational justice: The role of rational versus experiential processing in third-party reactions to workplace mistreatment. Journal of Applied Psychology, 95, 944-952. doi:10.1037/a0020468

Skjørshammer, M. (2003). Anger behaviour among professionals in a Norwegian hospital: : antecedents and consequences for interprofessional cooperation. Journal of Interprofessional Care, 17, 377-388. doi:10.1080/ 13561820310001608203

Sonnemans, J., \& Frijda, N. H. (1995). The determinants of subjective emotional intensity. Cognition and Emotion, 9, 483-506. doi:10.1080/02699939508408977

Spencer, S., \& Rupp, D. E. (2009). Angry, guilty, and conflicted: Injustice toward coworkers heightens emotional labor through cognitive and emotional mechanisms. Journal of Applied Psychology, 94, 429-444. doi:10.1037/ a0013804

Stickney, L. T., \& Geddes, D. (2014). Positive, proactive, and committed: The surprising connection between good citizens and expressed (vs. suppressed) anger at work. Negotiation and Conflict Management Research, 7, 243264. doi: $10.1111 / \mathrm{ncmr} .12040$

Tajfel, H., \& Turner, J. C. (1985). The social identity theory of intergroup behavior. In S. Worchel \& W. G. Austin (Eds.), Handbook of industrial and organizational psychology (2nd ed., Vol. 4, pp. 769-827). Palo Alto, CA: Consulting Psychologists Press.

Tavris, C. (1984). On the wisdom of counting to ten: Personal and social dangers of anger expression. In P. Shaver (Ed.), Review of personality and social psychology (Vol. 5, pp. 170-192). Newbury Park, CA: Sage.

Van Dyne, L., Ang, S., \& Botero, I. C. (2003). Conceptualizing employee silence and employee voice as multidimensional constructs. Journal of Management Studies, 40, 1359-1391. doi:10.1111/1467-6486.00384

Van Kleef, G.A. (2009). How emotions regulate social life: The emotions as social information (EASI) model. Current Directions in Psychological Science, 18, 184-188. doi:10.1111/j.1467-8721.2009.01633.x.

Van Kleef, G. A., Homan, A. C., \& Cheshin, A. (2012). Emotional influence at work: Take it EASI. Organizational Psychology Review, 2, 311-339. doi:10.1177/2041386612454911 
Van Kleef, G. A., Van Doorn, E. A., Heerdink, M. W., \& Koning, L. F. (2011). Emotion is for influence. European Review of Social Psychology, 22, 114-163. doi:10.1080/10463283.2011.627192

Viswesvaran, C., Sanchez, J. I., \& Fisher, J. (1999). The role of social support in the process of work stress: A meta-analysis. Journal of Vocational Behavior, 54, 314-334. doi:10.1006/jvbe.1998.1661

Weiss, H. M., \& Cropanzano, R. (1996). Affective events theory: A theoretical discussion of the structure, causes and consequences of affective experiences at work. In L. L. Cummings \& B. M. Staw (Eds.), Research in organizational behavior (Vol., 18, pp. 1-74). Greenwich, CT: JAI Press.

Zellars, K. L., \& Perrewé, P. L. (2001). Affective personality and the content of emotional social support: Coping in organizations. Journal of Applied Psychology, 86, 459-467. doi:10.1037/0021-9010.86.3.459

Lisa T. Stickney, Ph.D., is Associate Professor of Management at the University of Baltimore. She is a three-time recipient and current holder of the Dean James Chair for Distinguished Teaching. Her research interests include anger in organizations, gender studies, and management pedagogy. Her research has been published in Human Relations, Negotiation and Conflict Management Research, Research in Emotions in Organizations, Sex Roles: A Journal of Research, Organization and Management Journal, and the Journal of Management Education.

Deanna Geddes, Ph.D., is Associate Professor and Chair of Human Resource Management at the Fox School of Business, Temple University. She is the honoree of several teaching awards including the Musser Award for Leadership in Teaching. Her research interests focus on workplace emotion and performance feedback. Her conceptual and empirical work is published in the Academy of Management Review, Academy of Management Learning \& Education, Journal of Organizational Behavior, Human Relations, Aggressive Behavior, and Management Communication Quarterly, among others. 